\title{
Preference and drinking behavior of lactating dairy cows offered water with different concentrations, valences, and sources of iron
}

\author{
O. N. Genther ${ }^{1}$ and D. K. Beede ${ }^{2}$ \\ Department of Animal Science, Michigan State University, East Lansing 48824
}

\begin{abstract}
Drinking water can contain high concentrations of Fe, mainly of the ferrous $\left(\mathrm{Fe}^{2+}\right)$ valence. The current recommended upper tolerable concentration of $\mathrm{Fe}$ in drinking water for cattle $(0.3 \mathrm{mg} / \mathrm{L})$ comes from guidelines for human palatability, but cattle may be able to tolerate higher concentrations. Our objective was to determine the effects of varying concentrations of ferrous $\left(\mathrm{Fe}^{2+}\right)$ or ferric $\left(\mathrm{Fe}^{3+}\right)$ iron and Fe salt source on lactating dairy cows' preferences for and drinking behavior of water offered as choices ad libitum. In 4 separate experiments, cows were offered pairs of water treatments for 22-h periods and water intake and drinking behavior were recorded. In experiment 1 , treatments were 0,4 , or 8 $\mathrm{mg}$ of total recoverable $\mathrm{Fe} / \mathrm{L}$ from ferrous lactate. Cows exhibited no preference between water with 0 or $4 \mathrm{mg}$ of $\mathrm{Fe} / \mathrm{L}$, but water intake was less with 8 compared with 0 or $4 \mathrm{mg}$ of $\mathrm{Fe} / \mathrm{L}$. Also, cows spent less time drinking water containing $8 \mathrm{mg}$ of $\mathrm{Fe} / \mathrm{L}$. Total time spent drinking correlated positively with water intake when pooled across treatments. In experiment 2 , treatments were 0 or $8 \mathrm{mg}$ of $\mathrm{Fe} / \mathrm{L}$ from either ferrous sulfate $\left(\mathrm{FeSO}_{4}\right)$ or ferric sulfate $\left[\mathrm{Fe}_{2}\left(\mathrm{SO}_{4}\right)_{3}\right]$. Water intake did not differ among treatments. In experiment 3 , treatments were 0 (control), 12.5, or $8 \mathrm{mg}$ of $\mathrm{Fe} / \mathrm{L}$ from ferrous chloride $\left(\mathrm{FeCl}_{2}\right)$ or ferric chloride $\left(\mathrm{FeCl}_{3}\right)$, respectively. Again, cows exhibited no preference among treatments. In experiment 4, treatments were 0 or $8 \mathrm{mg}$ of $\mathrm{Fe} / \mathrm{L}$ from ferrous lactate $\left[\mathrm{Fe}\left(\mathrm{C}_{3} \mathrm{H}_{5} \mathrm{O}_{3}\right)_{2}\right]$, ferrous sulfate $\left(\mathrm{FeSO}_{4}\right)$, or ferrous chloride $\left(\mathrm{FeCl}_{2}\right)$. Cows preferred to drink water without added $\mathrm{Fe}$, but did not exhibit any preference among waters containing the Fe sources with different anionic moieties. Cows spent less time drinking and drank less frequently when offered water containing $12.5 \mathrm{mg}$ of total recoverable $\mathrm{Fe} / \mathrm{L}$ from ferrous chloride compared with $8.0 \mathrm{mg}$ of $\mathrm{Fe} / \mathrm{L}$ from ferrous lactate or ferrous sulfate. Water intake correlated positively with both drinking duration and frequency when pooled
\end{abstract}

\footnotetext{
Received June 26, 2012.

Accepted October 31, 2012.

${ }^{1}$ Current address: Department of Animal Science, Iowa State University, Ames 50011-3150.

${ }^{2}$ Corresponding author: beede@msu.edu
}

across treatments in experiment 4. Overall, our results indicate that upon first exposure to drinking water, lactating dairy cows tolerate concentrations of $\mathrm{Fe}$ up to $4 \mathrm{mg} / \mathrm{L}$ from ferrous lactate without reducing water intake; however, water intake was reduced with $8 \mathrm{mg}$ of total recoverable Fe. Preference did not appear to be influenced by Fe valence or added Fe source.

Key words: dairy cattle, drinking water, iron, drinking behavior

\section{INTRODUCTION}

Preference is the degree to which one alternative is preferred over another. A dairy cow's preference for drinking water is an indicator of its palatability that can be measured by differences in water intake and animal behavior. Anecdotal reports from the field suggest that drinking water with $\mathrm{Fe}$ concentrations of $2 \mathrm{mg} / \mathrm{L}$ or greater may affect milk production and cow health negatively (D. K. Beede, personal observation). These effects might be mediated (1) through changes in Fe or antioxidant status and oxidative stress of cows or (2) through preference for or against particular drinking waters. In the current research we focused on the latter.

The upper tolerable limit for Fe concentration in drinking water recommended for dairy cows $(0.3 \mathrm{mg} / \mathrm{L})$ is based on anecdotal suggestions of the acceptable concentration for palatability in humans (WHO, 2006). No research has attempted to establish this concentration in dairy cattle. Only one study has investigated the effects of drinking water contaminated with $\mathrm{Fe}$ in ruminants (Horvath, 1985). Sheep were offered simulated acid mine drainage water that often has high concentrations of $\mathrm{Fe}$ (approximately 25 to $500 \mathrm{mg} / \mathrm{L}$ ). The animals were offered the same treatments for 15 min twice daily for $2 \mathrm{~d}$. Iron concentrations of $75 \mathrm{mg} \mathrm{Fe} / \mathrm{L}$ as ferric sulfate or $145 \mathrm{mg} \mathrm{Fe} / \mathrm{L}$ from ferric chloride had no effect on water intake. However, it was not clear in the report if animals were offered alternative water for the other $23.5 \mathrm{~h}$ each day. Therefore, water consumption may not have reflected preference in a more normal setting with continuous access to water. Additionally, Fe concentrations of treatments were greater than typically found in drinking water for dairy cows in commercial farms. In a survey of 2,437 drinking water samples from livestock 
operations in the United States, average and maximum concentrations of Fe were 0.79 and $123 \mathrm{mg} / \mathrm{L}$, respectively (Socha et al., 2003). In over 980 samples from 3 provinces in Canada, Fe concentrations averaged 0.01 to $2.1 \mathrm{mg} / \mathrm{L}$, with maximum concentrations of about 30 mg/L (Osborne, 2006).

Palatability, as reflected by reduced DMI and ADG from supplemental $\mathrm{Fe}$ in rations, was characterized in calves and sheep. Calves fed dietary Fe of $750 \mathrm{mg} / \mathrm{kg}$ of DM from ferrous sulfate $\left(\mathrm{FeSO}_{4}\right)$ had reduced DMI and ADG (Hansen et al., 2010). Dietary Fe concentrations of $1,600 \mathrm{mg}$ of $\mathrm{Fe} / \mathrm{kg}$ from ferrous sulfate or ferric citrate $\left(\mathrm{FeC}_{6} \mathrm{H}_{5} \mathrm{O}_{7}\right)$ reduced DMI of sheep compared with those fed unsupplemented diets, although ferrous sulfate had a greater negative effect on DMI than ferric citrate (Standish and Ammerman, 1971). However, intake by dairy cows of pasture irrigated with water containing $17 \mathrm{mg}$ of $\mathrm{Fe} / \mathrm{L}$ from ferric hydroxide $\left[\mathrm{Fe}(\mathrm{OH})_{3}\right](17 \mathrm{mg}$ of $\mathrm{Fe} / \mathrm{L}$ ) was not different than that of cows on nonirrigated pasture (Coup and Campbell, 1964).

The World Health Organization suggests that Fe concentrations greater than $0.3 \mathrm{mg} / \mathrm{L}$ in drinking water will affect taste preference of humans (WHO, 2006). But, concentrations of 1 to $3 \mathrm{mg}$ of $\mathrm{Fe} / \mathrm{L}$ from anaerobic well water can be acceptable (WHO, 2003). Anaerobic water contains mostly ferrous iron $\mathrm{Fe}^{2+}$; Colter and Mahler, 2006); this suggests that $\mathrm{Fe}^{2+}$ may be more palatable than ferric iron $\left(\mathrm{Fe}^{3+}\right)$.

We hypothesized that as the concentration of $\mathrm{Fe}^{2+}$ in drinking water increases, water intake of lactating dairy cows would decrease; furthermore cows would prefer water with greater concentration of $\mathrm{Fe}^{2+}$ compared with $\mathrm{Fe}^{3+}$ when presented with the choice, but would prefer water with no supplemental $\mathrm{Fe}$ (low basal Fe concentration in control water) over any other source. Our objective was to determine if water intake and drinking behavior of lactating dairy cows differed when offered waters with ascending concentrations of $\mathrm{Fe}^{2+}$, different $\mathrm{Fe}$ valences $\left(\mathrm{Fe}^{2+}\right.$ or $\left.\mathrm{Fe}^{3+}\right)$, and from different Fe sources (salts).

\section{MATERIALS AND METHODS}

The Institutional Animal Care and Use Committee at Michigan State University (East Lansing) approved all procedures for the 4 experiments (approval no. 03/10024-00). All were conducted at the Michigan State University Dairy Teaching and Research Center in July to August (mean daily ambient temperature $=22.8^{\circ} \mathrm{C}$; mean maximum ambient temperature $=29.4^{\circ} \mathrm{C}$ ).

\section{Animals, Experimental Design, and Treatments}

This research focused on preference choices, water intake, and behavior of cows offered different drinking water treatments for relatively short periods of time. The general preexperimental (1 wk) measurements of water intake, feed intake, and milk yield and composition are given in (Table 1) to help characterize the cows. Means and standard deviations are listed for 6 cows used in experiments 1 through 3 , and for 12 cows used in experiment 4 . These data were not analyzed statistically because they were collected before experimental treatments were introduced. Furthermore, lactational performance (e.g., feed intake and milk yield) during the time cows were administered treatments was not evaluated statistically because of the short time of treatment administration. Ingredient and nutrient compositions of diets are given in Table 2 .

Experiment 1. Six mid-lactation Holstein cows (181 \pm 44 DIM; 2 primiparous and 4 multiparous) situated in tiestalls were assigned randomly in a replicated $3 \times$ 3 Latin square design involving 3 periods, 3 treatments, and in 3 possible paired treatment combinations. Experimental treatments were drinking water with: 0 $(\mathbf{0 F e}), 4(\mathbf{4 F e})$, or $8 \mathrm{mg}$ of $\mathrm{Fe} / \mathrm{L}(\mathbf{8 F e})$ from ferrous lactate $\left[\mathrm{Fe}\left(\mathrm{C}_{3} \mathrm{H}_{5} \mathrm{O}_{3}\right)_{2}\right]$ added to on-site tap water (Table 3). Treatments were formulated to contain 0,4 , or $8 \mathrm{mg}$ of $\mathrm{Fe} / \mathrm{L}$ of total recoverable $\mathrm{Fe}$ (preanalysis preparation by nitric acid digestion) or about 0,1 , and $2 \mathrm{mg}$ of $\mathrm{Fe} / \mathrm{L}$ by direct metals analysis (no preanalysis preparation; Midwest Laboratories Inc., Omaha, NE), both analyzed by inductively coupled plasma-atomic emission spectrometry per Environmental Protection Agency (EPA) method 200.7 (EPA, 1994). Drinking water treatments were in individual containers offered in pairs to each cow on the left and right sides of individual feed bunks with the TMR between the containers. Spatial arrangement of paired water treatments, diet, and cows were similar in all experiments. In experiment 1 , each cow was offered 1 of 3 possible paired combinations (0Fe and $4 \mathrm{Fe}, 0 \mathrm{Fe}$ and $8 \mathrm{Fe}$, or $4 \mathrm{Fe}$ and $8 \mathrm{Fe}$ ) in each of 3 experimental periods (each lasting $22 \mathrm{~h}$ ); pairs were balanced for left-right effect by representing each pair in both possible spatial orientations equally in each period.

Experiment 2. Six mid-lactation Holstein cows (187 \pm 44 DIM; 2 primiparous and 4 multiparous) from experiment 1 were kept in tiestalls and assigned randomly in a replicated $3 \times 3$ Latin square design with 3 experimental periods, 3 experimental treatments, and in 3 possible treatment pair combinations. Experimental treatments were: 0 (control) or $8 \mathrm{mg}$ of $\mathrm{Fe} / \mathrm{L}$ from either ferrous sulfate $\left(\mathrm{FeSO}_{4}\right)$ or ferric sulfate $\left(\left[\mathrm{Fe}_{2}\left(\mathrm{SO}_{4}\right)_{3}\right]\right)$ added to on-site tap water (Table 3 ). Treatments were formulated to contain 0 and $8 \mathrm{mg}$ of $\mathrm{Fe} / \mathrm{L}$ of total recoverable $\mathrm{Fe}$ or about 0 and $2 \mathrm{mg}$ of $\mathrm{Fe} / \mathrm{L}$, determined by direct metals analysis. Treatments were offered as pairs. Each cow was offered 1 
Table 1. General preexperimental characterization of daily water and DM intake, and milk yield and composition of cows in experiments 1 through $4^{1}$

\begin{tabular}{lccccc}
\hline & \multicolumn{2}{c}{ Experiments 1 through $3^{2}$} & & \multicolumn{2}{c}{ Experiment 4} \\
\cline { 2 - 3 } \cline { 5 - 6 } Variable & Mean & $\mathrm{SD}$ & & Mean & $\mathrm{SD}$ \\
\hline Water intake, L & 109.6 & 16.40 & & 108.3 & 18.75 \\
DMI, kg & 23 & 3.2 & & 23 & 3.5 \\
Milk yield, kg & 47.0 & 5.81 & & 45.3 & 7.03 \\
Milk components, ${ }^{3} \%$ & 3.02 & & & & \\
Fat & 2.74 & 0.13 & & 3.26 & 0.71 \\
True protein & 4.64 & 0.08 & & 2.81 & 0.46 \\
Lactose & 5.53 & 0.09 & & 5.57 & 0.73 \\
SNF & 150 & 187.5 & & 20 & 0.87 \\
SCC, $1,000 \mathrm{~mL}$ & 20.2 & 2.77 & & 25.2 & 34.52 \\
MUN, mg/dL & & & & & \\
\hline
\end{tabular}

${ }^{1}$ Information is listed for the 6 cows in experiments 1 through 3 and for the 12 cows in experiment 4 . These data were not analyzed statistically because they were collected before experimental treatments were imposed.

${ }^{2}$ Mean \pm SD of 6 cows in experiments 1 through 3 .

${ }^{3}$ Milk composition data were pooled for experiments 1, 2, and 3 .

of 3 possible pairs (control and ferrous sulfate, control and ferric sulfate, or ferrous sulfate and ferric sulfate) in each of 3 experimental periods; pairs were balanced for left-right effect by representing each pair in both possible spatial orientations equally in each period.

Experiment 3. Six mid-lactation Holstein cows (180 \pm 16 DIM; 1 primiparous and 5 multiparous) were assigned randomly in a replicated $3 \times 3$ Latin square design involving 3 experimental periods, 3 experimental treatments, and in 3 possible treatment pair combinations. Experimental treatments were: 0 (control) and $8 \mathrm{mg}$ of $\mathrm{Fe} / \mathrm{L}$ from either ferrous chloride $\left(\mathrm{FeCl}_{2}\right)$ or ferric chloride $\mathrm{FeCl}_{3}$ ) added to on-site tap water (Table $3)$. Treatments were formulated to contain 0 and $8 \mathrm{mg}$ of $\mathrm{Fe} / \mathrm{L}$ of total recoverable $\mathrm{Fe}$ or about 0 and $2 \mathrm{mg}$ of $\mathrm{Fe} / \mathrm{L}$ as determined by direct metals analysis. However, an error was made in treatment formulation using the incorrect number for waters of hydration in the chemical formula, so the ferrous chloride treatment actually contained $12.5 \mathrm{mg}$ of total recoverable $\mathrm{Fe} / \mathrm{L}(25 \%$ greater than formulated). Treatments were offered as pairs. Each cow was offered 1 of 3 possible treatment pairs (control and ferrous chloride, control and ferric chloride, or ferrous chloride and ferric chloride) in each of 3 experimental periods; pairs were balanced for leftright effect by representing each pair in both possible spatial orientations equally in each period.

Experiment 4. Twelve mid-lactation Holstein cows (135 \pm 18 DIM; 8 primiparous and 4 multiparous) kept in tiestalls were assigned randomly in a $6 \times 6$ Latin square design involving 6 experimental periods, 4 experimental treatments, and in 6 possible treatment pair combinations. Experimental treatments were: 0 (control) and $8 \mathrm{mg}$ of $\mathrm{Fe} / \mathrm{L}$ from ferrous lactate, ferrous sulfate, or ferrous chloride added to on-site tap water
(Table 3). Treatments were formulated to contain 0 and $8 \mathrm{mg}$ of $\mathrm{Fe} / \mathrm{L}$ of total recoverable $\mathrm{Fe}$ or about 0 and $2 \mathrm{mg}$ of $\mathrm{Fe} / \mathrm{L}$ by direct metals analysis. The ferrous chloride treatment actually contained $12.5 \mathrm{mg}$ of total recoverable $\mathrm{Fe} / \mathrm{L}$ (25\% greater concentration than formulated) as noted for experiment 3. Each cow was offered 1 of these 6 possible treatment pairs (control and ferrous lactate, control and ferrous sulfate, control and ferrous chloride, ferrous lactate and ferrous sulfate, ferrous lactate and ferrous chloride, or ferrous sulfate and ferrous chloride) in each of 6 experimental periods; pairs were balanced for left-right effect by representing each pair in both possible spatial orientations equally in each period.

\section{General Temporal Sequence of Each Experiment}

Each experiment was a Latin square design as described previously. Each experimental period within a square was 1 of 3 consecutive days of intensive measurements within each experiment. Prior to the intensive measurement periods, a preexperimental baseline period (acclimation period) consisted of $5 \mathrm{~d}$ of water intake measurement using water cups with in-line flow meters and from experimental water containers (all with control water) on d 6 and 7 . Individual cow daily feed intake and milk yield also were measured in the preexperimental baseline period to characterize general performance (Table 1). Milk samples for component analysis were taken on the last day (a.m. and p.m. milkings) of each experimental period. These data were not analyzed statistically due to the short time interval of experimental treatment administration. During each experiment, on the last $3 \mathrm{~d}$ (each a period in the Latin square design in experiments 1 through 3 ) and last $6 \mathrm{~d}$ 
Table 2. Ingredient and analyzed nutrient composition of diets fed in experiments 1 through 4

\begin{tabular}{|c|c|c|}
\hline Item & $\begin{array}{l}\text { Experiments } \\
1 \text { through } 3^{1}\end{array}$ & Experiment 4 \\
\hline \multicolumn{3}{|c|}{ Ingredient, $\%$ of dietary DM } \\
\hline Chopped alfalfa hay & 3.74 & 3.93 \\
\hline Corn silage & 35.63 & 33.61 \\
\hline Whole cottonseed & 5.70 & 6.20 \\
\hline Energy Booster $100^{2}$ & 0.40 & 0.42 \\
\hline Grass hay & 4.83 & 5.17 \\
\hline Ground corn & 9.52 & 10.09 \\
\hline Alfalfa haylage & 9.86 & 8.89 \\
\hline High-moisture corn & 6.98 & 7.41 \\
\hline Soybean meal, $48 \%$ CP & 14.64 & 15.19 \\
\hline Soy hulls & 5.25 & 5.55 \\
\hline Mineral-vitamin $\operatorname{mix}^{3}$ & 3.27 & 3.45 \\
\hline \multicolumn{3}{|l|}{ Nutrient composition } \\
\hline DM, \% & 49.40 & 46.60 \\
\hline \multicolumn{3}{|l|}{$\%$ of dietary DM } \\
\hline $\mathrm{NDF}$ & 32.90 & 34.50 \\
\hline $\mathrm{ADF}$ & 22.20 & 22.60 \\
\hline $\mathrm{CP}$ & 17.84 & 17.95 \\
\hline $\mathrm{Ca}$ & 1.11 & 1.06 \\
\hline $\mathrm{P}$ & 0.35 & 0.37 \\
\hline $\mathrm{K}$ & 1.26 & 1.34 \\
\hline $\mathrm{Na}$ & 0.31 & 0.35 \\
\hline $\mathrm{S}$ & 0.22 & 0.37 \\
\hline $\mathrm{Mg}$ & 0.24 & 0.25 \\
\hline \multicolumn{3}{|l|}{$\mathrm{mg} / \mathrm{kg}$} \\
\hline Co & 0.11 & 0.12 \\
\hline $\mathrm{Cu}$ & 10.1 & 10.9 \\
\hline $\mathrm{Fe}$ & 257 & 179 \\
\hline Mo & 1.8 & 2.2 \\
\hline $\mathrm{Mn}$ & 42 & 46 \\
\hline $\mathrm{Zn}$ & 41 & 42 \\
\hline
\end{tabular}

${ }^{1}$ Feed ingredients were pooled for experiments 1 through 3 for the values reported in this table.

${ }^{2}$ Milk Specialties Global Animal Nutrition, Carpentersville, IL.

${ }^{3}$ Mineral-vitamin mix contained $47.5 \%$ limestone, $22.5 \%$ sodium bicarbonate, $10.1 \%$ urea $(45 \% \mathrm{~N}), 8.2 \%$ magnesium sulfate, $7.5 \%$ sodium chloride, $1.6 \%$ biotin premix $(1.4 \mathrm{~g} / \mathrm{kg}), 1.3 \%$ trace mineral premix [supplemented from cobalt carbonate, copper sulfate, ethylenediaminodihydroiodide (EDDI), ferrous sulfate, manganese sulfate, and zinc sulfate], $30 \mathrm{kIU}$ of vitamin $\mathrm{A} / \mathrm{kg}, 8 \mathrm{kIU}$ of vitamin $\mathrm{D} / \mathrm{kg}, 56 \mathrm{kIU}$ of vitamin $\mathrm{E} / \mathrm{kg}$, and $0.3 \%$ selenium yeast.

of experiment 4, intensive measurements of 2 -h water preference, intake, and behavior were made.

\section{Water Intake Measurement} and Behavior Assessment

Water Intake Measurement. For all 4 experiments, all cows were adapted to drinking on-site tap (control) water from the experimental water containers before initiation of the experiments. On the days of experimental measurements, water containers were removed from access by the cows approximately $2 \mathrm{~h}$ before the experimental period commenced. Cows were removed from tiestalls and taken to the milking parlor approximately $1 \mathrm{~h}$ after water containers were removed. Thus, cows were without drinking water for about $2 \mathrm{~h}$ before experimental water treatments were

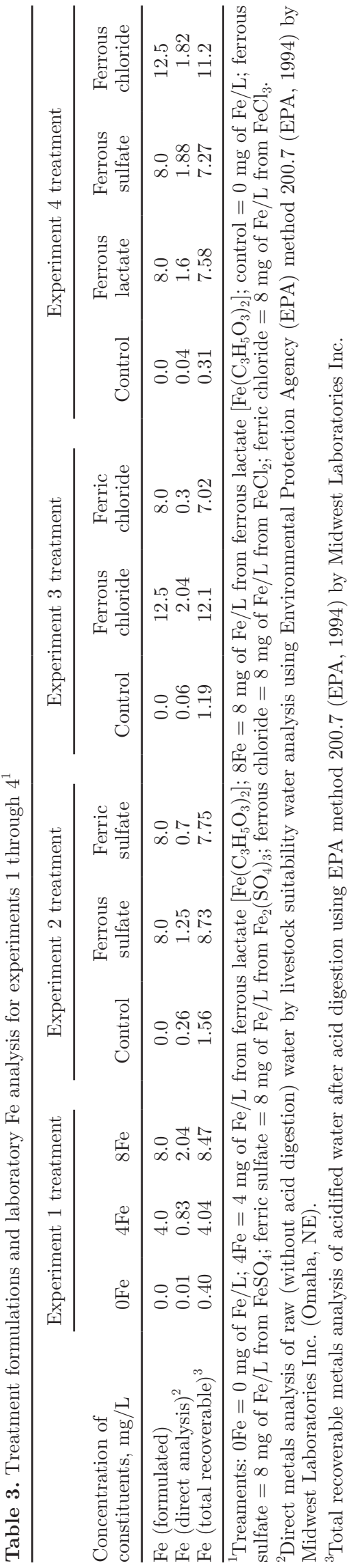

Journal of Dairy Science Vol. 96 No. 2, 2013 
introduced. While cows were in the milking parlor, containers were scrubbed with detergent, thoroughly rinsed, and filled with experimental waters according to treatment assignments. Water containers were placed on the left and right sides in the preset spatial configuration within each individual feed bunk. The remaining $50 \%$ of the ration, withheld during morning feeding, was added in the bunks to the residual ration from the previous feeding. Cows returned to their respective tiestalls simultaneously, immediately after milking, to individual access to ration and 2 water containers containing experimental treatments. At this time $(1600 \mathrm{~h})$, the period ( $12 \mathrm{~h}$ total/period) of intensive water intake measurements and recording of cows' drinking behavior from visual observation began by 1 attendant per cow.

Every $2 \mathrm{~h}$, all containers were removed from all feed bunks at the same time by attendants, and behavior recording was paused. The water in each container was skimmed with a swimming pool skimmer to remove any feed that had dropped into the containers when cows ate during the experimental period. Water containers were weighed. If the weight was less than approximately $45 \mathrm{~kg}$, the container was refilled in increments of 5 or $10 \mathrm{~L}$, until the weight reached greater than $45 \mathrm{~kg}$. All containers were then replaced in proper predetermined left or right position in each feed bunk at the same time and the behavior observation and recording resumed. Behavior recording lasted a total of $12 \mathrm{~h}$. At the end of $12 \mathrm{~h}$, containers were weighed, refilled with the experimental water treatments, and replaced in position in the bunks.

Initially, some cows pushed containers from position in the bunk to access feed. If containers were pushed more than $20 \mathrm{~cm}$ away from the bunk, they immediately were replaced in position in the bunk within the cow's reach by the attendant. If the cow habitually pushed containers away, they were fastened in position with rubber straps attached to the tiestall pipes that did not interfere with drinking. If less than about $10 \mathrm{~L}$ of water was in a container before scheduled refilling, all containers were removed from all bunks for refilling. No containers were ever empty, each cow was always able to drink from either container in its bunk, and spillage was minimal.

Water containers remained in position in the bunks for cows to access continuously from h 12 through 22 . They were checked at $0900 \mathrm{~h}$, weighed, and refilled, and finally removed and weighed at the end of the experimental period $(1400 \mathrm{~h})$. The total experimental period was $22 \mathrm{~h}$. At the beginning of the next experimental period $(1600 \mathrm{~h})$, cows were offered the next randomly assigned treatment pair combination for a $22-\mathrm{h}$ period. This continued for the length of the experiment (three 22-h periods for experiments 1 through 3 , and six 22 -h periods for experiment 4 ).
Behavior Assessment. Drinking behavior events were recorded for the initial $12 \mathrm{~h}$ of each experimental period in each experiment and categorized for analyses. Events and duration of events recorded were drinking, lapping, and "other". Drinking was defined as a cow fully or partially submerging her muzzle in water to consume water. Lapping was defined as a cow consuming water without submerging her muzzle. The "other" category included all other behaviors associated with containers when cows were not actively drinking water. Examples of other nonconsumptive behaviors included splashing, sniffing, and pushing containers with the muzzle. Frequency of cow interaction with water containers also was recorded and evaluated. Behavior measurements were recorded to the nearest $1 \mathrm{~s}$. The beginning of one behavior signified the end of the previous behavior, with continuous monitoring, so only the beginning time of each behavior was recorded. If a behavior was associated with a specific water container and treatment it was recorded. Other common behaviors and durations recorded included consuming ration, ruminating, urinating, defecating, standing up, lying down, resting, and standing.

\section{Preparation of Treatments}

Treatments were prepared in the laboratory in concentrated form (100 times the final treatment solution concentrations) in 1-L polypropylene bottles. During preparation of final treatments, concentrated solutions were diluted with on-site tap water at the Dairy Teaching and Research Center (water composition in Table 4) until the proper concentration and volume (50 L) were reached.

\section{Water Containers}

Water was offered in two 75-L capacity white Rubbermaid Brute (Rubbermaid Commercial Products, Winchester, VA) storage tote containers (width: 38.4 $\mathrm{cm} \times$ height: $44.1 \mathrm{~cm} \times$ length: $70.8 \mathrm{~cm}$ ) each placed in the left or right side within each individual cow's feed bunk with feed situated between the containers. There was a vacant tiestall between cows to avoid social interactions that potentially might affect water intake or behavior. In preliminary testing of water intake from white, yellow, and gray containers, color did not affect intake of on-site tap water.

\section{Training (Preexperimental)}

Nine days before the beginning of each experiment, cows were offered on-site tap water in the experimental containers for $48 \mathrm{~h}$ to familiarize them with containers. 
Table 4. Water quality constituent analysis of on-site tap (control) drinking water in experiments 1 through 4

\begin{tabular}{|c|c|c|c|c|c|}
\hline \multirow[b]{2}{*}{ Item } & \multicolumn{4}{|c|}{ Experiment } & \multirow{2}{*}{$\begin{array}{c}\text { Caution } \\
\text { level }^{1}\end{array}$} \\
\hline & 1 & 2 & 3 & 4 & \\
\hline \multicolumn{6}{|l|}{ Constituent, mg/L } \\
\hline $\mathrm{TDS}^{2}$ & 377 & 462 & 411 & 387 & 1,000 \\
\hline $\mathrm{Ca}$ & 86 & 114 & 99 & 92 & 150 \\
\hline $\mathrm{Cl}$ & 21 & 15 & 25 & 16 & 500 \\
\hline $\mathrm{Cu}^{3}$ & $\mathrm{ND}^{4}$ & ND & ND & ND & 0.3 \\
\hline $\mathrm{Fe}$ (direct $\mathrm{Fe}$ analysis) ${ }^{5}$ & 0.07 & 0.26 & 0.06 & 0.04 & 0.3 \\
\hline $\mathrm{Fe}(\text { total recoverable })^{3}$ & 0.4 & 1.56 & 1.19 & 0.31 & - \\
\hline $\mathrm{Mg}$ & 30 & 38 & 31 & 31 & 80 \\
\hline $\mathrm{Mn}^{3}$ & 0.06 & 0.75 & 0.06 & 0.03 & - \\
\hline $\mathrm{NO}_{3}-\mathrm{N}$ & ND & ND & ND & ND & 25 \\
\hline $\mathrm{Na}$ & 9 & 7 & 11 & 7 & 150 \\
\hline $\mathrm{SO}_{4}$ & 53 & 122 & 59 & 61 & 300 \\
\hline $\mathrm{Zn}$ & 0.17 & 0.14 & 0.06 & 0.14 & - \\
\hline Conductivity, $\mathrm{mS} / \mathrm{cm}$ & 0.58 & 0.71 & 0.63 & 0.59 & 1.5 \\
\hline $\mathrm{pH}$ & 7.8 & 7.7 & 7.7 & 7.6 & $6.5-9.0$ \\
\hline
\end{tabular}

${ }^{1}$ Caution levels from Midwest Laboratories Inc. (Omaha, NE).

${ }^{2} \mathrm{TDS}=$ total dissolved solids.

${ }^{3}$ From total recoverable metals analysis of acidified water after acid digestion using Environmental Protection Agency (EPA) method 200.7 (EPA, 1994) by Midwest Laboratories Inc.

${ }^{4} \mathrm{ND}=$ not detected.

${ }^{5}$ Direct metals analysis of raw (without acid digestion) water by livestock water analysis using EPA method 200.7 (EPA, 1994) by Midwest Laboratories Inc.

Containers were removed from the bunks, weighed, and refilled every 6 h during training. Every 24 h, containers were removed, emptied, scrubbed with detergent, rinsed well, and refilled. Following the initial training period, cows were placed in tiestalls with individual automatic water cups, as in the normal setting, and water intake was measured with in-line water flow meters (model FT8000B; Omega Engineering Inc., Stamford, $\mathrm{CT}$ ) for $5 \mathrm{~d}$ to establish baseline water intake. In the $48 \mathrm{~h}$ immediately before actual data collection with experimental treatments, cows were moved to individual tiestalls without automatic water cups, and water was provided only in the experimental water containers for reacclimation and to establish baseline intake from water containers. All cows were exposed to water containers for the same length of time during preexperimental acclimation periods and there always was an unoccupied tiestall on each side of each cow.

\section{Common Feeding, Water, and Milk Data Collection and Analyses}

A basal diet formulated to meet or exceed NRC (2001) recommendations for all nutrients (including Fe) was fed ad libitum throughout each experiment (Table 2 ). Cows were fed once daily in their individual tiestalls, and taken twice daily to the milking parlor. Milk yield and water and feed intake were recorded daily for the entire experiment, including acclimation periods. Preexperimental feed intake and milk yield and composi- tion are presented in Table 1 to further characterize the experimental animals. All cows ate and drank normal amounts during the preexperimental periods (Table 1). These results did not reflect responses to experimental treatments because treatments were only administered during the last $3 \mathrm{~d}$ of each experiment.

Feed intakes were measured daily throughout the experiment. Individual feed ingredients were sampled the week before each data collection period began, and again between experimental periods. Each individual feed sample was weighed and dried in a forced-air oven at $55^{\circ} \mathrm{C}$ for $72 \mathrm{~h}$ until completely dry to determine DM percentage. Dried samples were ground through a 2-mm screen in a Wiley mill (Arthur H. Thomas Co., Philadelphia, PA) before analysis. Samples of each individual ingredient were pooled by experiment and sent for nutrient analysis by Dairy One Laboratories (Ithaca, NY). Milk samples were taken once per experiment from one a.m. and p.m. milking and sent for composition analysis at Michigan DHIA Universal Laboratory Services (Lansing, MI; Table 1).

Drinking water treatments were sampled each period as solutions were added to containers. Samples were pooled within experiment and 1 sample per treatment in each experiment was analyzed for $\mathrm{Fe}$ by each of 2 separate methods. Raw (unprocessed) water samples were sent to Midwest Laboratories Inc. for direct metals analysis [livestock suitability water analysis; EPA method 200.7 (EPA, 1994)]. A second sample was acidified $(\mathrm{pH}<2.0)$ with $1 \mathrm{~mL}$ of nitric acid, and sent to the 
same laboratory for acid digestion and metals analyses [total recoverable metals analysis using EPA method 200.7 (EPA, 1994)]. Internal water reference samples containing $0,1,4$, or $8 \mathrm{mg}$ of $\mathrm{Fe} / \mathrm{L}$ from ferrous lactate were placed randomly in triplicate as unknowns within the sets experimental treatment samples for analysis. The intraassay coefficient of variation was $4.0 \%$. Laboratory analysis results of experimental water treatments are presented in Table 3.

\section{Statistical Analyses}

The experimental design was a replicated Latin Square with a split plot in which treatments were subplot units within cow, period, and treatment pair whole plots. Data were analyzed by method of least-squares ANOVA using the PROC MIXED of SAS (version 9.2; SAS Institute Inc., Cary, NC). Differences in cumulative and noncumulative (2-h time periods) water intakes were compared among treatments. Data of 2-h measurements were analyzed using the REPEATED statement, and the covariance structure that resulted in the lowest Bayesian information criterion (BIC) was used. Fixed effects in the model included treatment, time (2-h interval measurements), and treatment by time interaction. Random effects included cow and period. If the interaction term was not significant $(P>$ $0.15)$, data were analyzed separately by time. Residual distributions were tested for normality using the Shapiro-Wilk test), and outliers were identified using Cook's D statistic distribution. During evaluation of the full model, including interaction terms, intake data were transformed by taking the square root to accommodate the assumptions of normality. During analyses of individual 2-h water intake responses and total behavior responses, if required, data also were transformed to either square root or natural log to accommodate the assumptions of normality. Results were back transformed for presentation. Differences between or among treatments were identified using the PDIFF option with the Tukey adjustment. Least squares means are presented. Significance for treatment main effects was declared at $P<0.05$, and a trend toward significance at $P<0.10$. Significance for interaction effects was declared at $P$ $<0.10$, and a trend toward significance at $P<0.15$. Pearson correlation coefficients were calculated to explore relationships between water intake and behavior responses using the CORR procedure of SAS.

\section{RESULTS AND DISCUSSION}

\section{Treatment Effects on Water Intake}

Experiment 1. Our objective was to examine the effects of drinking water Fe concentration on preference.
Cows were offered pairs of drinking water treatments with 0,4 , or $8 \mathrm{mg}$ of total recoverable $\mathrm{Fe} / \mathrm{L}$ supplied from ferrous lactate. We were concerned initially that cows might be induced to drink water containing additional Fe because it would be novel to them; however, this did not occur. Overall, no interaction of treatment by time was observed for either cumulative $(P=0.96)$ nor noncumulative water intake $(P=0.98)$. An overall effect of treatment $(P<0.05)$ was observed at the end of the total experimental period (22 h; Table 5$)$. Additionally, at the end of the experimental period, intake of $4 \mathrm{Fe}$ tended to be greater than intake of $8 \mathrm{Fe}$ $(P=0.07)$, but not different from 0Fe. Horvath (1985) found that sheep offered $145 \mathrm{mg}$ of $\mathrm{Fe} / \mathrm{L}$ from ferric sulfate $\mathrm{Fe}_{2}\left(\mathrm{SO}_{4}\right)_{3}$ had reduced water intake, but when Fe concentration was reduced to $75 \mathrm{mg}$ of $\mathrm{Fe} / \mathrm{L}$ from the same source, water intake was not different from that of the control. We expected that $0 \mathrm{Fe}$ would be more acceptable to lactating dairy cows than $4 \mathrm{Fe}$, but $4 \mathrm{mg}$ of $\mathrm{Fe} / \mathrm{L}$ did not affect drinking water preference. Also, no differences in total water intakes occurred, due to which pairs of treatments were offered. These results suggest that $0.3 \mathrm{mg}$ of $\mathrm{Fe} / \mathrm{L}$ suggested as the upper tolerable concentration for lactating dairy cows is less than practically necessary. However, further evaluation is warranted to evaluate $\mathrm{Fe}^{2+}$ concentrations between 4 and $8 \mathrm{mg} / \mathrm{L}$, and the potential contributions of valence and source of $\mathrm{Fe}$ in drinking water on preference and intake.

Experiments 2 and 3. In experiment 2, we assessed the effects of iron valence $\left(\mathrm{Fe}^{2+}\right.$ vs. $\left.\mathrm{Fe}^{3+}\right)$ on drinking water preference. Cows were offered pairs of water treatments with 0 or $8 \mathrm{mg}$ of total recoverable $\mathrm{Fe} / \mathrm{L}$ as either ferrous sulfate or ferric sulfate. No interaction of treatment by time on cumulative $(P=0.97)$ or noncumulative $(P=0.69)$ water intake existed over the 22 -h period. Overall, no differences in total water intakes were observed among treatments $(P=0.28$; Table 5). However, total water intake of cows offered the control treatment was at least $10 \mathrm{~L}$ greater than that of cows offered the other treatments. Throughout the 22-h period, water intakes by cows offered control and ferric sulfate treatments were numerically similar (from h 0 through 17) until $22 \mathrm{~h}$, when intake of the control treatment was numerically higher. No interaction between treatment and time was observed. Also, no difference existed in total water intake due to the specific pairs of treatments offered.

In experiment 3 , we evaluated effects of difference in Fe valence on drinking water preference using 0 or $8 \mathrm{mg}$ of total recoverable $\mathrm{Fe} / \mathrm{L}$ from either ferrous chloride or ferric chloride offered to cows as pairs of treatments. The ferrous chloride treatment actually contained 12.5 $\mathrm{mg}$ of $\mathrm{Fe} / \mathrm{L}$, due to not accurately accounting for the 
Table 5. Water intake and drinking behavior duration for experiments 1 through $4^{1}$

\begin{tabular}{|c|c|c|c|c|c|c|c|c|c|c|c|}
\hline \multirow[b]{3}{*}{ Item } & \multicolumn{5}{|c|}{ Experiment 1} & \multicolumn{6}{|c|}{ Experiment 2} \\
\hline & \multicolumn{3}{|c|}{ Treatment } & \multirow[b]{2}{*}{ SEM } & \multirow[b]{2}{*}{$P$-value } & \multicolumn{3}{|c|}{ Treatment } & \multirow[b]{2}{*}{ SEM } & \multirow[b]{2}{*}{$P$-value } & \\
\hline & $0 \mathrm{Fe}$ & $4 \mathrm{Fe}$ & $8 \mathrm{Fe}$ & & & Control & $\begin{array}{l}\text { Ferrous } \\
\text { sulfate }\end{array}$ & $\begin{array}{l}\text { Ferric } \\
\text { sulfate }\end{array}$ & & & \\
\hline $\begin{array}{l}\text { 22-h water intake, } \mathrm{L} \\
\text { Behavior duration, } \mathrm{s}\end{array}$ & 60.4 & 61.9 & $46.1 \dagger$ & 4.80 & 0.05 & 68.1 & 50.6 & 56.1 & 7.78 & 0.28 & \\
\hline Drinking & $210^{\mathrm{a}}$ & $214^{\mathrm{a}}$ & $124^{\mathrm{b}}$ & 28.7 & 0.01 & 182 & 119 & 156 & 50.5 & 0.558 & \\
\hline Lapping & 196 & 226 & 234 & 84.8 & 0.65 & 210 & 187 & 182 & 71.7 & 0.82 & \\
\hline \multirow[t]{4}{*}{ Other ${ }^{2,3}$} & 30 & 28 & 39 & 18.8 & 0.76 & 14 & 15 & 15 & 8.0 & 0.99 & \\
\hline & \multicolumn{5}{|c|}{ Experiment 3} & \multicolumn{6}{|c|}{ Experiment 4} \\
\hline & \multicolumn{3}{|c|}{ Treatment } & & & \multicolumn{4}{|c|}{ Treatment } & & \\
\hline & Control & $\begin{array}{l}\text { Ferrous } \\
\text { chloride }\end{array}$ & $\begin{array}{c}\text { Ferric } \\
\text { chloride }\end{array}$ & SEM & $P$-value & Control & $\begin{array}{l}\text { Ferrous } \\
\text { lactate }\end{array}$ & $\begin{array}{l}\text { Ferrous } \\
\text { sulfate }\end{array}$ & $\begin{array}{l}\text { Ferrous } \\
\text { chloride }\end{array}$ & SEM & $P$-value \\
\hline $\begin{array}{l}\text { 22-h water intake, } \mathrm{L} \\
\text { Behavior duration, } \mathrm{s}\end{array}$ & 63.8 & 47.4 & 67.3 & 9.35 & 0.29 & $71.9^{\mathrm{a}}$ & $53.3^{\mathrm{b}}$ & $45.8^{\mathrm{b}}$ & $43.0^{\mathrm{b}}$ & 5.11 & $<0.0001$ \\
\hline Drinking ${ }^{4}$ & 221 & 96 & 199 & 69.6 & 0.22 & $316^{\mathrm{a}}$ & $222^{\mathrm{ab}}$ & $200^{\mathrm{ab}}$ & $106^{\mathrm{b}}$ & 49.5 & 0.004 \\
\hline Lapping ${ }^{5}$ & 131 & 127 & 194 & 66.5 & 0.67 & 213 & 205 & 291 & 257 & 67.1 & 0.37 \\
\hline Other $^{2,6}$ & 46 & $19 \ddagger$ & 56 & 30.9 & 0.09 & 143 & 124 & 113 & 124 & 35.1 & 0.93 \\
\hline
\end{tabular}

a,b Means within a row with different superscripts differ $(P<0.05)$.

${ }^{1}$ Treaments: $0 \mathrm{Fe}=0 \mathrm{mg}$ of $\mathrm{Fe} / \mathrm{L} ; 4 \mathrm{Fe}=4 \mathrm{mg}$ of $\mathrm{Fe} / \mathrm{L}$ from ferrous lactate $\left[\mathrm{Fe}\left(\mathrm{C}_{3} \mathrm{H}_{5} \mathrm{O}_{3}\right)_{2}\right] ; 8 \mathrm{Fe}=8 \mathrm{mg}$ of $\mathrm{Fe} / \mathrm{L}$ from ferrous lactate $\left[\mathrm{Fe}\left(\mathrm{C}_{3} \mathrm{H}_{5} \mathrm{O}_{3}\right)_{2}\right]$; control $=0 \mathrm{mg}$ of $\mathrm{Fe} / \mathrm{L}$; ferrous c sulfate $=8 \mathrm{mg}$ of $\mathrm{Fe} / \mathrm{L}$ from $\mathrm{FeSO}_{4}$; ferric sulfate $=8 \mathrm{mg}$ of Fe/L from $\mathrm{Fe}_{2}\left(\mathrm{SO}_{4}\right)_{3}$; ferrous chloride $=8 \mathrm{mg}$ of $\mathrm{Fe} / \mathrm{L}$ from FeCl 2 ferric chloride $=8 \mathrm{mg}$ of $\mathrm{Fe} / \mathrm{L}$ from $\mathrm{FeCl}_{3}$; ferrous lactate $=8 \mathrm{mg}$ of $\mathrm{Fe} / \mathrm{L}$ in experiment 4 . Note: ferrous chloride concentrations in experiments 3 and 4 were greater than formulated (Table 3 ).

疍 ${ }^{2}$ Other = behaviors involving cows interacting with water containers, but not consuming water (nonconsumptive behavior).

을 $\quad{ }^{3}$ Data were square root-transformed for analysis and LSM and SEM were back-transformed for presentation in this table.

D. Data were natural log-transformed for analysis and LSM and SEM were back-transformed for presentation in this table.

离. $\quad{ }^{5}$ For experiment 3, data were natural log-transformed for analysis and LSM and SEM were back-transformed; for experiment 4, data were root-transformed for analysis and LSM C) and SEM were back-transformed.

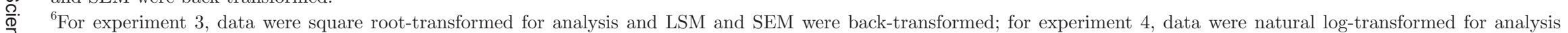
?ָ

$\lesssim \quad \dagger$ Tended to be lower than $4 \mathrm{Fe}(P<0.10)$; ttended to be lower than ferric chloride $(P<0.10)$. 
waters of hydration in calculation and preparation of the treatment solution. No effect of treatment was observed on total water intake (Table 5). No interaction occurred between treatment and time for cumulative $(P=1.0)$ or noncumulative $(P=0.54)$ water intakes. No effect of pairs of treatments offered was observed on water intake. Although not statistically different, water intake of cows offered ferrous chloride (12.1 mg of total recoverable $\mathrm{Fe} / \mathrm{L}$ ) was numerically less than the other treatments throughout the experimental period. These results are similar to those of experiment 2 . In both experiments, intakes of cows of waters containing $\mathrm{Fe}^{2+}$ were numerically less than that of other treatments offered. We suspect that measurements with more cows in the design would strengthen the experiment; variance estimates for these measurements from other similar experiments were not available in the literature to calculate power.

During both experiments 2 and 3, a change in the visual appearance of $\mathrm{Fe}^{2+}$ (ferrous sulfate and ferrous chloride) and $\mathrm{Fe}^{3+}$ (ferric sulfate and ferric chloride) treatments was noted. Throughout the experimental measurement period (each $22 \mathrm{~h}$ in length), colors of $\mathrm{Fe}^{2+}$ treatments increased from clear to reddish-brown, presumably due to exposure to air and oxidation of Fe. The treatment waters remained cloudy throughout the measurement period with suspended matter, presumably containing Fe. The $\mathrm{Fe}^{3+}$ treatments also increased in coloration; however, the precipitate sunk to the bottom more readily instead of staying suspended, as occurred with the $\mathrm{Fe}^{2+}$ treatments. This left a reddish sediment at the bottom of the water containers, but the water above remained relatively clear. We suspect that cows had numerically greater intakes of water containing $\mathrm{Fe}^{3+}$ than $\mathrm{Fe}^{2+}$ because the $\mathrm{Fe}$ was more evenly distributed in the water column of the $\mathrm{Fe}^{2+}$ treatments. We suggest that the more even distribution of $\mathrm{Fe}^{2+}$ had a negative effect on drinking water palatability.

Experiment 4. Iron has a strong tendency to form organic and inorganic salt complexes (e.g., ferrous lactate, ferrous sulfate, and ferric oxide) with other elements (Hem and Cropper, 1959). It is not known if Fe salt complexes have an effect on palatability of drinking water. In experiment 4 , our objective was to determine if cow preference was dependent on Fe source (salt) supplied in the drinking water. Cows were offered pairs of water treatments containing 0 or $8 \mathrm{mg}$ of total recoverable $\mathrm{Fe} / \mathrm{L}$ as ferrous lactate, ferrous sulfate, or ferrous chloride; the ferrous chloride treatment actually had $12.5 \mathrm{mg}$ of $\mathrm{Fe} / \mathrm{L}$ as described for experiment 3. No interaction of treatment by time existed for either cumulative $(P=0.20)$ or noncumulative $(P=0.58)$ water intake. An overall effect of treatments on total water intake $(P<0.0001$; Table 5$)$ was observed. Cows pre- ferred to drink the control water source compared with every treatment with supplemental Fe. No difference in water intake by cows offered the 3 different sources of ferrous Fe $(P>0.15)$ was observed. This result is different from results of the study by Horvath (1985) in which wethers offered $145 \mathrm{mg}$ of $\mathrm{Fe} / \mathrm{L}$ from either ferric sulfate or ferric chloride preferred water containing ferric chloride. Digesti and Weeth (1976) also found that water palatability, measured as total water intake, was reduced more by sodium sulfate than an equal anionic concentration of sodium chloride (concentrations ranged from 275 to $4,400 \mathrm{mg} / \mathrm{L}$ ). In our study, the concentrations of lactate, sulfate, and chloride were relatively lower, and likely did not have nearly as much effect on palatability as the concentrations of supplemental Fe. These results also suggest that the anion of the salt associated with $\mathrm{Fe}$ in drinking water does not reduce the palatability of water with relatively high $\mathrm{Fe}$ concentration (8 $\mathrm{mg}$ of $\mathrm{Fe} / \mathrm{L}$ ).

\section{Perspectives on Sample Preparation and Fe Analysis in Water}

Water samples from treatments were collected throughout our experiments. They were prepared for analysis of Fe by each of 2 different methods: (1) the direct metals analysis method of raw water (without acidification and acid digestion of the sample), known as the livestock suitability water analysis by Midwest Laboratories Inc. (https://www.midwestlabs.com/ content/view/66/218/) and (2) the total recoverable metals analysis, which uses acidification of the water and acid digestion before analysis. Samples from both preparations were analyzed for Fe using EPA method 200.7 (EPA, 1994) by Midwest Laboratories Inc. Overall, the concentrations of Fe determined by the direct metals analysis were only 7 to $25 \%$ as much as those formulated or determined by the total recoverable metals analysis (Table 3 ). The direct $\mathrm{Fe}$ analysis typically has been used in the field to evaluate water quality in some dairy farms (D. K. Beede, personal observation). The direct metals analysis is used routinely to analyze irrigation water samples (B. Blessing, Midwestern Laboratories Inc., personal communication).

In our experiments, cows drank less water with $\mathrm{Fe}$ concentrations of $8 \mathrm{mg}$ of $\mathrm{Fe}^{2+} / \mathrm{L}$, as determined by the total recoverable metals analysis. Therefore, our results indicate that in the field, $2 \mathrm{mg}$ of $\mathrm{Fe} / \mathrm{L}$, if determined by the direct analysis method (without acidification of the sample at the laboratory), may be closer to $8 \mathrm{mg}$ of total recoverable $\mathrm{Fe} / \mathrm{L}$, which could negatively affect water intake. In short, the concentrations of Fe that we offered cows through our high-Fe drinking water treatments were almost 4-fold greater than we had believed 
previously if one used the Fe concentration values from the direct metals analysis (livestock suitability water analysis of Midwest Laboratories Inc.). Obviously, for research or for field evaluation of potential problems of Fe in drinking water, it is very important to understand if the direct metals analysis or the total recoverable $\mathrm{Fe}$ analysis (with sample acidification and acid digestion) is conducted. Doubtless, the total recoverable analysis is the method of choice (all Fe present is detected) and should be the standard of comparison.

\section{Treatment Effects on Drinking Behavior}

Drinking behavior was monitored for the first $12 \mathrm{~h}$ of the 22-h measurement in each experimental period in each experiment. Our objective was to determine if Fe concentration, valance, and source affected drinking water behavior durations, total time spent interacting with each water treatment, and frequency of interactions with each treatment. The main behaviors assessed were drinking, lapping, and nonconsumption interactions.

Experiment 1. We hypothesized that as concentrations of $\mathrm{Fe}$ increased, total duration and frequency of drinking and lapping would decrease, and time spent interacting with the container, but not consuming water would increase. Cows spent more time drinking $0 \mathrm{Fe}$ and $4 \mathrm{Fe}$ than the $8 \mathrm{Fe}$ treatment $(P=0.05$; Table 5$)$. Water intake also was greater for cows offered both $0 \mathrm{Fe}$ and $4 \mathrm{Fe}$ water treatments than the $8 \mathrm{Fe}$ treatment. No other treatment effects were observed on duration of other behaviors. No difference existed in the frequency of occurrence of any of the drinking behaviors. Total time spent at water containers and visit frequencies were not different due to treatment.

Experiment 2. Coinciding with our hypothesis related to water intake, we suspected that cows would spend more time drinking the control water than the Fe-supplemented treatments, and more time drinking water of the ferrous sulfate treatment than the ferric sulfate treatment. We also hypothesized that time spent interacting with the containers, not consuming water, would be greatest for ferric sulfate. No treatment effect was observed on duration or frequency of drinking behaviors (Table 5). Also, no effect of treatment was observed on total time spent nor on frequency of visits to water containers.

Experiment 3. Similar to our hypothesis in experiment 2, we expected that drinking duration and frequency would be greater for ferrous chloride than ferric chloride, and greatest for the control treatment water. We also expected that cows would spend more time interacting with, but not consuming ferric chloride water. No treatment effect existed on duration nor frequency of drinking behaviors, with the exception of a slight tendency for the ferrous chloride treatment to cause a reduction in time spent interacting with the water container while not consuming water in "other" activities (Table 5), following the trend for reduced water intake. In addition, no effect of treatment was observed on total time spent at each water container nor frequency of visits.

Experiment 4. We expected that cows would spend more time drinking and drink more often from the control water treatment, and no differences in behaviors would exist among Fe source treatments. No effect of treatment was observed on frequency nor duration of lapping or nonconsumption behaviors (Table 5). An effect of treatment on drinking duration $(P=0.005)$ and frequency (data not shown; $P=0.03$ ) was observed. Cows spent more time drinking from the control, ferrous lactate, and ferrous sulfate treatments than from the ferrous chloride treatment $(P=0.02)$, and tended to spend more total time drinking from the ferrous lactate treatment than the ferrous chloride treatment $(P=0.07)$. However, this effect may be due to the somewhat greater concentration of additional Fe contained in the ferrous chloride treatment as previously described. Overall, cows drank more frequently from the control water treatment (11.2 times $/ 12 \mathrm{~h})$ compared with the supplemental Fe treatments $(8.7,8.6$, and $6.7 \pm 2.15$ times $/ 12 \mathrm{~h}$ for ferrous lactate, ferrous sulfate, and ferrous chloride, respectively; $P<0.03$ ). Treatment did not affect the total time spent at each container or the number of visits per container during the 12-h observation period.

\section{Correlations Between Drinking Behavior and Water Intake}

The relationships between various drinking behavior durations and frequencies were investigated for individual treatments and pooled across treatments for each experiment. Correlations were done for 12-h total behavior durations and corresponding 12 -h total water intake.

Experiment 1. Relationships and correlation coefficients between drinking behaviors and water intake were compared. Positive correlations existed between drinking duration $(\mathrm{r}=0.65 ; P<0.05)$ and frequency $(\mathrm{r}$ $=0.74 ; P<0.05)$ with total water intake in $12 \mathrm{~h}$ for the 0Fe treatment (Table 6). Pooled across all treatments, drinking duration $(\mathrm{r}=0.62 ; P<0.05)$ and drinking frequency $(\mathrm{r}=0.56 ; P<0.05)$ were correlated positively with total 12 -h water intake. When pooled across treatments, no correlations existed between lapping duration or frequency with total water intake. However, water intake of the $0 \mathrm{Fe}$ treatment tended to be cor- 
Table 6. Pearson correlation coefficients for relationships between drinking behavior and 12-h water intake in experiments 1 through $4^{1}$

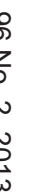

\begin{tabular}{|c|c|c|c|c|c|c|c|c|c|}
\hline \multirow[b]{3}{*}{ Item } & \multicolumn{4}{|c|}{ Experiment 1} & \multicolumn{5}{|c|}{ Experiment 2} \\
\hline & \multicolumn{3}{|c|}{ Treatment } & \multirow[b]{2}{*}{$\begin{array}{c}\text { Pooled across } \\
\text { treatments }\end{array}$} & \multicolumn{3}{|c|}{ Treatment } & \multirow[b]{2}{*}{$\begin{array}{c}\text { Pooled across } \\
\text { treatments }\end{array}$} & \\
\hline & $0 \mathrm{Fe}$ & $4 \mathrm{Fe}$ & $8 \mathrm{Fe}$ & & Control & $\begin{array}{l}\text { Ferrous } \\
\text { sulfate }\end{array}$ & $\begin{array}{l}\text { Ferric } \\
\text { sulfate }\end{array}$ & & \\
\hline \multicolumn{10}{|l|}{ Drinking } \\
\hline Duration & 0.65371* & $0.51433 \dagger$ & 0.47432 & $0.62254^{*}$ & $0.68347^{*}$ & $0.56967 \dagger$ & $0.84163^{*}$ & $0.70464^{*}$ & \\
\hline Frequency & $0.74011^{*}$ & 0.34511 & 0.31158 & $0.55553^{*}$ & 0.41922 & $0.66291^{*}$ & $0.58211^{*}$ & $0.52143^{*}$ & \\
\hline \multicolumn{10}{|l|}{ Lapping } \\
\hline Duration & $-0.53377 \dagger$ & $0.64785^{*}$ & 0.27885 & 0.08379 & 0.43651 & 0.25246 & 0.31928 & 0.31817 & \\
\hline Frequency & -0.01356 & $0.56509 \dagger$ & 0.26319 & 0.22740 & $0.62491^{*}$ & 0.08924 & 0.35114 & 0.28454 & \\
\hline \multicolumn{10}{|l|}{ Other $^{2}$} \\
\hline Duration & 0.31802 & -0.02181 & -0.11572 & 0.06227 & -0.08649 & -0.35700 & -0.10997 & -0.15631 & \\
\hline \multirow[t]{4}{*}{ Frequency } & 0.49544 & 0.00658 & -0.18433 & 0.14325 & -0.11826 & -0.11070 & 0.13946 & -0.06315 & \\
\hline & \multicolumn{4}{|c|}{ Experiment 3} & \multicolumn{5}{|c|}{ Experiment 4} \\
\hline & \multicolumn{3}{|c|}{ Treatment } & & \multicolumn{4}{|c|}{ Treatment } & \\
\hline & Control & $\begin{array}{l}\text { Ferrous } \\
\text { chloride }\end{array}$ & $\begin{array}{l}\text { Ferric } \\
\text { chloride }\end{array}$ & $\begin{array}{l}\text { Pooled across } \\
\text { treatments }\end{array}$ & Control & $\begin{array}{l}\text { Ferrous } \\
\text { lactate }\end{array}$ & $\begin{array}{l}\text { Ferrous } \\
\text { sulfate }\end{array}$ & $\begin{array}{l}\text { Ferrous } \\
\text { chloride }\end{array}$ & $\begin{array}{c}\text { Pooled across } \\
\text { treatments }\end{array}$ \\
\hline \multicolumn{10}{|l|}{ Drinking } \\
\hline Duration & 0.49667 & 0.38998 & $0.52901 \dagger$ & 0.42773 & $0.45451^{*}$ & $0.32436 \dagger$ & $0.42433^{*}$ & $0.42816^{*}$ & 0.42142 \\
\hline Frequency & 0.48297 & -0.07224 & $0.54007 \dagger$ & 0.41004 & $0.39526^{*}$ & $0.48484^{*}$ & $0.43335^{*}$ & $0.32048 \dagger$ & 0.41149 \\
\hline \multicolumn{10}{|l|}{ Lapping } \\
\hline Duration & 0.29902 & -0.21694 & $0.61865^{*}$ & 0.35768 & 0.10954 & 0.05615 & 0.22615 & $0.38021^{*}$ & 0.11925 \\
\hline Frequency & 0.43217 & -0.46821 & $0.62511^{*}$ & 0.33905 & -0.03270 & 0.12386 & 0.08579 & $0.30659 \dagger$ & 0.06866 \\
\hline \multicolumn{10}{|l|}{ Other } \\
\hline Duration & $0.76286^{*}$ & -0.36625 & $0.58239 \dagger$ & 0.38706 & 0.27511 & 0.26315 & $0.28772 \dagger$ & 0.25306 & 0.28659 \\
\hline Frequency & $0.53779 \dagger$ & -0.40534 & $0.56597 \dagger$ & 0.34541 & 0.22752 & 0.03329 & 0.09249 & $0.39405^{*}$ & 0.18444 \\
\hline
\end{tabular}

${ }^{1}$ Treaments: $0 \mathrm{Fe}=0 \mathrm{mg}$ of $\mathrm{Fe} / \mathrm{L} ; 4 \mathrm{Fe}=4 \mathrm{mg}$ of $\mathrm{Fe} / \mathrm{L}$ from ferrous lactate $\left[\mathrm{Fe}\left(\mathrm{C}_{3} \mathrm{H}_{5} \mathrm{O}_{3}\right)_{2}\right] ; 8 \mathrm{Fe}=8 \mathrm{mg}$ of Fe$/ \mathrm{L}$ from ferrous lactate $\left[\mathrm{Fe}\left(\mathrm{C}_{3} \mathrm{H}_{5} \mathrm{O}_{3}\right)_{2}\right] ;$ control $=0 \mathrm{mg}$ of $\mathrm{Fe} / \mathrm{L} ;$ ferrous sulfate $=8 \mathrm{mg}$ of $\mathrm{Fe} / \mathrm{L}$ from $\mathrm{FeSO}_{4}$; ferric sulfate $=8 \mathrm{mg}$ of $\mathrm{Fe} / \mathrm{L}$ from $\mathrm{Fe}_{2}\left(\mathrm{SO}_{4}\right)_{3}$; ferrous chloride $=8 \mathrm{mg}$ of $\mathrm{Fe} / \mathrm{L}$ from FeCl 2 ; ferric chloride $=8 \mathrm{mg}$ of Fe $/ \mathrm{L}$ from $\mathrm{FeCl}{ }_{3}$; ferrous lactate $=8 \mathrm{mg}$ of $\mathrm{Fe} / \mathrm{L}$ in experiment 4 . Note: ferrous chloride concentrations in experiments 3 and 4 were greater than formulated (Table 3).

${ }^{2}$ Other $=$ behaviors involving cows interacting with water containers, but not consuming water (nonconsumptive behavior).

$\dagger P<0.10 ; * P<0.05$. 
related negatively with lapping duration $(\mathrm{r}=-0.53$; $P<0.10$ ), whereas lapping duration was correlated positively with water intake in the 4 Fe treatment $(\mathrm{r}=$ 0.65; $P<0.05$ ), but not related in the $8 \mathrm{Fe}$ treatment $(\mathrm{r}=0.28 ; P>0.15)$. Pooled across treatments, no correlations were observed between 12 -h water intake and lapping nor other nonconsumption behavior frequencies nor durations (Table 6).

Experiment 2. Pooled across treatments, both drinking duration $(\mathrm{r}=0.70 ; P<0.05)$ and drinking frequency $(\mathrm{r}=0.52 ; P<0.05)$ were correlated positively with water intake (Table 6). No other relationships existed between drinking behaviors and water intake.

Experiment 3. No significant correlations were observed between drinking behavior durations or frequencies and 12-h water intake (Table 6). However, an interesting trend was identified among treatments. Most of the correlations between behavior and water intake were negative for the ferrous chloride treatment (Table 6 ). This was in contrast to control and ferric chloride treatments, in which all relationships between behavior and water intake were positive. These differences could be due to the somewhat greater concentration of $\mathrm{Fe}$ or the valence of the ferrous chloride treatment. Overall, no correlations existed between water intake and behavior when responses were pooled across all experimental treatments.

Experiment 4. Correlations and relationships between individual treatment water intakes and drinking behaviors were visually examined, and were similar across treatments (Table 6). Pooled across treatments, no correlative relationships were found.

Overall, Fe concentration and source had the greatest effect on drinking duration. Research by Dado and Allen (1994) indicated that lactating cows in tiestalls spent approximately $18.5 \mathrm{~min} / \mathrm{d}$ drinking and drank 4.3 $\mathrm{L} / \mathrm{min}$. In our experiments, cows spent approximately $8.8 \mathrm{~min} / 12 \mathrm{~h}$ drinking $(17.6 \mathrm{~min} / 24 \mathrm{~h})$ and drank 8.3 $\mathrm{L} / \mathrm{min}$. However, our estimate does not include time spent lapping. The differences between our results and those of Dado and Allen (1994) can be attributed to differences in cow water intake (about 108 vs. 77.6 $\mathrm{L} / \mathrm{d})$, milk production rate $(45 \mathrm{~kg} / \mathrm{d}$ and $33 \mathrm{~kg} / \mathrm{d})$, and the season in which the experiments took place (August vs. January). Among all experiments, the maximum difference in total time spent drinking was only approximately $200 \mathrm{~s}$ (difference between drinking duration of control and ferrous chloride treatments in experiment 4). However, this could translate to a decrease of 29.3 $\mathrm{L} /$ cow per day in water intake. This decrease is illustrated by the positive correlation between time spent drinking (duration) and total water intake among all experiments.

\section{CONCLUSIONS}

Our results indicate that the upper tolerable concentration of $\mathrm{Fe}$ in drinking water for cattle should be reevaluated. Total recoverable Fe concentration of $4 \mathrm{mg} / \mathrm{L}$ did not negatively affect the drinking water preference of lactating dairy cows when compared with water containing no supplemental Fe. Water intake was less with total recoverable $\mathrm{Fe}$ of $8 \mathrm{mg}$ of $\mathrm{Fe}^{2+} / \mathrm{L}$. However, as we have shown, the total recoverable concentrations of $\mathrm{Fe}$ in drinking water were about 4 times greater than conventionally believed, based on a typical direct livestock suitability water analysis often used in field evaluation. This implies that drinking water with $2 \mathrm{mg}$ of $\mathrm{Fe} / \mathrm{L}$ on farm, analyzed by this direct analysis method, could have the same negative effects as total recoverable $\mathrm{Fe}$ concentration of $8 \mathrm{mg} / \mathrm{L}$. Additionally, cows did not exhibit a preference between $\mathrm{Fe}^{2+}$ or $\mathrm{Fe}^{3+}$ in water, and did not have a preference for Fe source comparing ferrous salts of lactate, sulfate, or chloride. Drinking duration was negatively affected by greater Fe concentration and was dependent on source. This research indicates that potential effects of high $\mathrm{Fe}$ in drinking water on productivity and health could be due, at least in part, to reduced water intake resulting from reduction in palatability of drinking water.

\section{ACKNOWLEDGMENTS}

The work of the employees at the Michigan State University Dairy Teaching and Research Center (East Lansing) and of the numerous undergraduate students who helped in the laboratory, with data collection, and with behavior observations of the cows is gratefully acknowledged. The C. E. Meadows Endowment supported this research.

\section{REFERENCES}

Colter, A., and R. L. Mahler. 2006. Iron in drinking water. Pacific Northwest Bulletin No. 589. Pacific Northwest Extension Publication. University of Idaho, Moscow.

Coup, M. R., and A. G. Campbell. 1964. The effect of excessive iron intake upon the health and production of dairy cows. N. Z. J. Agric. Res. 7:624-638.

Dado, R. G., and M. S. Allen. 1994. Variation in and relationships among feeding, chewing, and drinking variables for lactating dairy cows. J. Dairy Sci. 77:132-144.

Digesti, R. D., and H. J. Weeth. 1976. A defensible maximum for inorganic sulfate in drinking water of cattle. J. Anim. Sci. 42:14981502 .

EPA (US Environmental Protection Agency). 1994. Method 200.7. Determination of metals and trace elements in water and wastes by inductively coupled plasma-atomic emission spectrometry. Revision 4.4. Accessed Apr. 20, 2011. http://www.epa.gov/sam/pdfs/ EPA-200.7.pdf.

Hansen, S. L., M. S. Ashwell, A. J. Moeser, R. S. Fry, M. D. Knutson, and J. W. Spears. 2010. High dietary iron reduces transporters in- 
volved in iron and manganese metabolism and increases intestinal permeability in calves. J. Dairy Sci. 93:656-665.

Hem, J. D., and W. H. Cropper. 1959. Chemistry of iron in natural water: survey of ferrous-ferric chemical equilibria and redox potentials. US Geol. Survey Water-Supply Paper 1459-A. US Geological Survey, Reston, VA.

Horvath, D. J. 1985. Consumption of simulated acid mine water by sheep. J. Anim. Sci. 61:474-479.

NRC. 2001. Nutrient Requirements of Dairy Cattle. 7th rev. ed. Natl. Acad. Sci., Washington, DC.

Osborne, V. R. 2006. Water, the forgotten nutrient. Pages 197-210 in Proc. West. Can. Dairy Seminar. University of Alberta, Edmonton, AB, Canada.
Socha, M. T., S. M. Ensley, D. J. Tomlinson, and A. B. Johnson. 2003. Variability of water composition and potential impact on animal performance. Pages 85-96 in Proc. Intermountain Nutr. Conf. Utah State University, Logan.

Standish, J. F., and C. B. Ammerman. 1971. Effect of excess dietary iron as ferrous sulfate and ferric citrate on tissue mineral composition of sheep. J. Anim. Sci. 33:481-484.

WHO (World Health Organization). 2003. Iron in drinking-water. Background document for development of WHO guidelines for drinking-water quality. WHO, Geneva, Switzerland.

WHO (World Health Organization). 2006. Guidelines for drinking water quality. Vol. 1. 3rd ed. WHO, Geneva, Switzerland. 